ENVIRONMENTAL RESTORATION PROGRAM

\section{Best Management Practices Plan for the Chestnut Ridge-Filled Coal Ash Pond at the Oak Ridge Y-12 Plant, Oak Ridge, Tennessee}

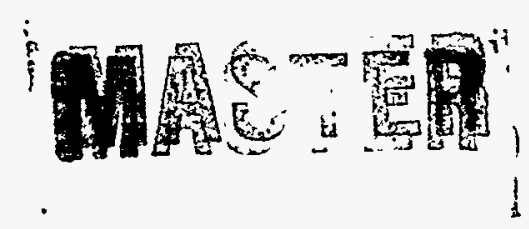

This document has been approved by the Y-12 Plant Technical Information Qffice for release to the public. Date: $5 / 30 / 96$

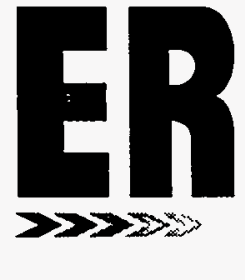




\section{Foster Wheeler Environmental Corporation}

contributed to the preparation of this document and should not be considered an eligible contractor for its review.

This report has been reproduced directly from the best available copy.

Available to DOE and DOE contractors from the Office of Scientific and Technical Information, P.O. Box 62, Oak Ridge, TN 37831; prices available from 423-576-8401 (fax 423-576-2865).

Available to the public from the National Technical Information Service, U.S. Department of Commerce, 5285 Port Royal Rd., Springfield, VA 22161. 


\section{DISCLAIMER}

This report was prepared as an account of work sponsored by an agency of the United States Government. Neither the United States Government nor any agency thereof, nor any of their employees, make any warranty, express or implied, or assumes any legal liability or responsibility for the accuracy, completeness, or usefulness of any information, apparatus, product, or process disclosed, or represents that its use would not infringe privately owned rights. Reference herein to any specific commercial product, process, or service by trade name, trademark, manufacturer, or otherwise does not necescarily constitute or imply its endorsement, recommendation, or favoring by the United States Government or any agency thereof. The views and opinions of authors expressed herein do not necessarily state or reflect those of the United States Government or any agency thereof. 


\section{DISCLAIMER}

Portions of this document may be illegible in electronic image products. Images are produced from the best available original document. 
Energy Systems Environmental Restoration Program

\section{Best Management Practices Plan for the Chestnut Ridge-Filled Coal Ash Pond at the Oak Ridge Y-12 Plant, Oak Ridge, Tennessee}

Date Issued-May 1996

Prepared by

Foster Wheeler Environmental Corporation Oak Ridge, Tennessee under subcontract 32M-03542C

Prepared for the

U.S. Department of Energy Office of Environmental Management under budget and reporting code EW 20

Environmental Management Activities at the OAK RIDGE Y-12 PLANT

Oak Ridge, Tennessee 37831-8169 managed by

LOCKHEED MARTIN ENERGY SYSTEMS, INC. for the U.S. DEPARTMENT OF ENERGY under contract DE-AC05-84OR21400 


\section{PREFACE}

This document, Best Management Practices Plan for the Chestnut Ridge-Filled Coal Ash Pond at the Oak Ridge Y-12 Plant, Oak Ridge, Tennessee, Y/ER-268, was prepared in accordance with requirements under the Comprehensive Environmental Response, Compensation, and Liability Act of 1980. This work was performed under Work Breakdown Structure 1.4.12.1.1.01.42 and Activity Data Sheet Number 2301, "Chestnut Ridge Operable Unit 2." Publication of this document provides the Environmental Restoration Program with the best management practices plan for the remediation project. 


\section{CONTENTS}

ACRONYMS $\ldots \ldots \ldots \ldots \ldots \ldots \ldots \ldots \ldots \ldots \ldots \ldots \ldots \ldots \ldots \ldots$

$1.0 \quad$ INTRODUCTION $\ldots \ldots \ldots \ldots \ldots \ldots \ldots \ldots \ldots \ldots \ldots \ldots \ldots$

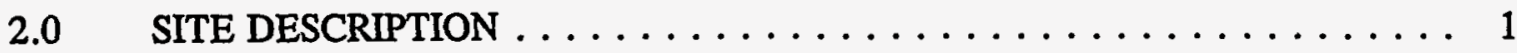

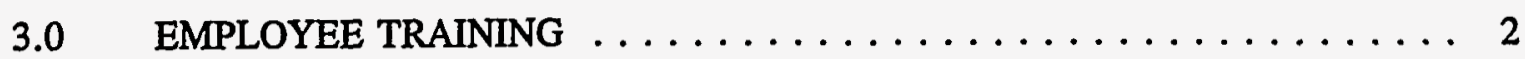

4.0 PRINCIPAL SAFETY, FIRE, AND HEALTH HAZARDS . . . . . . . . 3

5.0 SPILL PREVENTION AND CONTROL $\ldots \ldots \ldots \ldots \ldots \ldots$

6.0 WATER QUALITY MONITORING $\ldots \ldots \ldots \ldots \ldots \ldots$

7.0 GOOD HOUSEKEEPING PRACTICES $\ldots \ldots \ldots \ldots \ldots \ldots \ldots$

8.0 SEDIMENT AND EROSION CONTROL MEASURES . . . . . . . . . 4

9.0 INSPECTIONS AND ENVIRONMENTAL COMPLIANCE $\ldots \ldots \ldots \ldots$

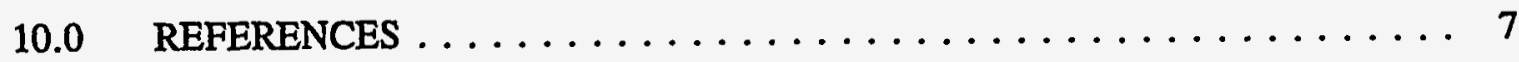

APPENDIX A: LOCATION PLAN/SITE ACCESS PLAN $\ldots \ldots \ldots \ldots \ldots \ldots$ 


\section{$\cdot$ ACRONYMS}

BMP Best Management Practices

CERCLA Comprehensive Environmental Response,

Compensation, and Liability Act

CFC Certified for Construction

CFR Code of Federal Regulations

DOE U.S. Department of Energy

Energy Systems Lockheed Martin Energy Systems, Inc.

EPA

FCAP

U.S. Environmental Protection Agency

HSEA Y-12 Health, Safety, Environment, and Accountability

NFPA National Fire Protection Association

NPDES National Pollutant Discharge Elimination System

ORNL Oak Ridge National Laboratory

ORO . Oak Ridge Operations

ORR Oak Ridge Reservation

SPCC Spill Prevention, Control, and Countermeasures

SSHO Site Safety and Health Officer 


\subsection{INTRODUCTION}

The U.S. Department of Energy (DOE) has three major operating facilities on the DOE Oak Ridge Reservation (ORR) in Oak Ridge, Tennessee: the Oak Ridge Y-12 Plant, the Oak Ridge K-25 Site, and the Oak Ridge National Laboratory (ORNL). The Y-12 Plant and K-25 Site are managed by Lockheed Martin Energy Systems, Inc. (Energy Systems); and ORNL is managed by Lockheed Martin Energy Research, Inc., for the DOE. The Chestnut Ridge Filled Coal Ash Pond (FCAP) Project has been established to satisfy Comprehensive Environmental Response, Compensation, and Liability Act (CERCLA) requirements for the Chestnut Ridge Operable Unit 2.

The purpose of this document is to provide a site-specific Best Management Practices (BMP) Plan for construction associated with environmental restoration activities at the FCAP Site. The BMP shall be used in conjunction with the plantwide baseline document, Y-12 Plant Best Management Practices (BMP) Plan. ${ }^{1}$

Section 304(e) of the Clean Water Act enables the Administrator of the U.S. Environmental Protection Agency (EPA) to control point source releases of pollutants. The National Pollutant Discharge Elimination System (NPDES) requires that facilities with the potential for releasing pollutants to the waters of the United States submit a BMP Plan, as specified in the Code of Federal Regulations (CFR) in 40 CFR 125, Subpart K, as a part of the discharge permit application.

According to the Energy Systems Environmental and Waste Management Policy,

It is company policy to establish and to maintain waste management, pollution control, and surveillance programs which are consistent with the company and DOE policy and which meet the requirements of federal, state, and local regulations to assure that installation personnel, the general public, and the environment are protected against hazardous pollutants. ${ }^{2}$

Implementation of the BMP Plan will be initiated by providing a copy to all parties involved in the FCAP remedial action construction. Recurring formal site inspections will be made during facility construction. All site inspections will be recorded to assure compliance with the provisions of this BMP Plan. Site inspections will be made on a weekly basis and after storm events.

\subsection{SITE DESCRIPTION}

FCAP is on Chestnut Ridge, approximately 0.5 miles south of the Y-12 Plant. A 62-foot high earthen dam across Upper McCoy Branch was constructed in 1955 to create a pond to serve as a settling basin for fly and bottom ashes generated by burning coal at the Y-12 Steam Plant. Ash from the steam was mixed with water to form a slurry and then pumped to the crest of Chestnut Ridge and released through a large pipe to flow across the Sluice Channel area and into the pond. The ash slurry eventually overtopped the dam and flowed along Upper McCoy Branch to Rogers 
Quarry. In 1989, a bypass pipe was constructed to carry the slurry directly to the quarry from the steam plant. All discharges from the steam plant to the ash pond stopped in 1989. Since then ash deposits in the ash pond, Upper McCoy floodplain, and the Sluice Channel Area have been left in place. The site is now well vegetated. Past investigations have revealed the existence of seeps in the downstream face of the dam; and as a result of this seepage, a wetland has formed at the toe of the dam. The existing spillway located on the eastern side of the dam has undergone severe erosion, and trees have become established and are growing on the downstream face of the dam. The hillside located east of the dam is steep and has been determined to be unstable.

The selected remedy involves the following actions to be taken to the site. The existing dam will be rehabilitated by clearing all trees from the downstream dam face, raising and widening the top of the dam, constructing a blanket drainage system, and placing additional fill material on the downstream face of the dam to provide additional stability. These improvements will extend the toe of the dam beyond its present location into an area presently occupied by the wetland (which is approximately 0.11 acres in size). The existing spillway will be repaired and improved to enhance the long-term stability of the dam. The eastern hillside adjacent to the dam will be regraded to provide a stable slope. Fill material excavated from the eastern hillside will be used as borrow material for dam and spillway improvement activities. Excess borrow material will be stockpiled at a location south of the dam, away from the Upper McCoy Branch floodplain.

Additional environmental enhancements are also planned. These include construction of an oxygenation area and settling basin below the downstream toe of the dam, which is intended to lessen the migration of contaminants from ash into the surface water. The wetland, located at the toe of the existing dam, will be relocated further downstream from the dam, adjacent to the settling basin. The relocation of the wetland involves the removal and stockpiling of existing wetland soils and vegetation. Wetland relocation activities will be sequenced to minimize impact to the existing wetland soils and plant material.

\subsection{EMPLOYEE TRAINING}

Energy Systems and MK-Ferguson employees receive a broad range of environmental, health, and safety training based on their job requirements. Environmental awareness is raised by issuing periodic bulletins concerning such topics as spill control. Supervisors are responsible for providing on-the-job training with respect to hazardous materials handling and company environmental policy.

Contractors and subcontractors performing work at the FCAP will be required to comply with Energy Systems and DOE environmental policy, including the provisions of this BMP Plan. Contractor foremen are responsible for their employees. All site personnel are to perform the work as specified in the Certified for Construction (CFC) drawings and specifications, and as directed by the Construction Manager. 


\subsection{PRINCIPAL SAFETY, FIRE, AND HEALTH HAZARDS}

System and equipment selections will conform to DOE-ORO (Oak Ridge Operations) requirements. Use of the latest editions of applicable codes is required. Concerns regarding potential health hazards can be directed to the project Site Safety and Health Officer (SSHO).

Construction operations and general construction personnel will be subject to normal and industrial hazards, and appropriate precautions must be taken.

\subsection{SPILL PREVENTION AND CONTROL}

The Spill Prevention Control and Countermeasures (SPCC) Plan for the Y-12 Plant provides guidance concerning roles and responsibilities of employees. ${ }^{3}$ Only that portion directly related to construction at the FCAP is summarized here.

All possible precautions shall be taken to minimize the likelihood of a spill. All containers over 5 gal are required to be labeled with the appropriate Hazardous Identification Label (diamond) as identified in the National Fire Protection Association (NFPA) Code NFPA-704. ${ }^{4}$

All heavy equipment and mechanical equipment will be maintained in good repair to minimize the release of engine, transmission, or other oils through slow leaks. Idle equipment will be parked as far away from streambeds as practical. A drip pan will be provided immediately by the Contractor for use under equipment that is leaking. The Construction Manager may require the Contractor to repair or replace any leaking equipment at any time.

Fueling operations will be performed with care, and allowances will be made for fuel expansion to prevent inadvertent small releases. Fuel tanks will be contained within temporary dikes and inspected regularly. Material spilled by contractors, if any, will be cleaned up daily, placed in appropriate containers, and properly disposed of.

If a spill occurs at the FCAP, all safe and practical methods available will be used to prevent material from entering streams, ponds, or springs. Spills will be reported immediately to the Construction Manager during construction and to the Plant Shift Superintendent office in all cases at 574-7172. Spill response kits containing absorbent material will be provided by the Construction Manager during construction. Absorbent pillows, temporary earth dikes, or other means will be readily available onsite and will be used as appropriate without risking personnel safety.

The FCAP drains into Upper McCoy Branch, which flows into Rogers Quarry. Discharge from Rogers Quarry crosses Bethel Valley Road and eventually drains into Melton Hill Lake. Water quality monitoring will be performed by Y-12 Health, Safety, Environment, and Accountability 
(HSEA) in accordance with NPDES regulations. Every effort will be made to minimize any effect construction may have on surface waters.

\subsection{GOOD HOUSEKEEPING PRACTICES}

Good housekeeping practices will be observed by all personnel present at the FCAP at all times. Paper trash and refuse will be collected and removed on a regular basis. No unpermitted wastewater of any type will be discharged onsite. All rinse water containing additives of any sort (e.g., soap, degreasers, cleaning agents) will be collected, contained, and properly disposed of. Trucks hauling material will not be overfilled. Loose debris will be contained within the vehicles to prevent littering of highways and haul roads. Brush, construction debris, and trash will be removed from drainage ways and streams. Brush will not be placed near streams in order to prevent residue from entering the streams.

Fueling operations will be conducted so that small fuel/oil releases are contained and cleaned up daily. Appropriate precautions are to be taken to minimize discharge of fuel, oil, lubricants, grease, and other hydrocarbons. Rinsing of cement residues will be performed in an approved area away from streams, ditches, or other water bodies.

\subsection{SEDIMENT AND EROSION CONTROL MEASURES}

Erosion is a natural phenomenon that is greatly increased by the removal of existing vegetation and earthwork activities associated with construction. Excessive erosion causes physical damage in the watershed due to increased water velocity. Unchecked sediment can increase turbidity and suffocate streambed flora and fauna under a blanket of silt. Erosion controls placed during the construction phase will minimize soil movement and will be installed as early as possible during the construction phase.

A primary concern of this BMP Plan is to provide erosion and sediment control measures. Several excellent references are available $(5,6$ and 7$)$ for additional information. All site work must conform to the CFC drawings and specifications and the directions of the Construction Manager. Deviations from the design require prior authorization from the Construction Manager.

Several actions to lessen the environmental impact due to erosion will be taken during the FCAP construction:

- Every effort will be made to keep disturbed areas to a minimum. Habitat disturbance will be minimized during clearing.

- Soils excavated onsite will be used as fill material.

- Existing natural drainage will be maintained where possible to avoid disturbing off-site areas. 
- If excavated soil is stockpiled, it will be spread and uniformly compacted. Silt fence will be placed around the stockpile area. Upon completion of soil stockpile areas, side slopes and completed top elevations of these stockpiles will be seeded and mulched. Overseeding or reseeding will be performed as required until vegetation is established. Soil stockpiles will not be located in floodplain areas.

- Straw bale barriers will be staked/secured and will be used in minor swales, ditches, and within the Upper McCoy Branch floodplain.

- Silt fences will be placed at the bottom of disturbed slopes, where appropriate.

- Storm drain entrance and exit will be protected with riprap.

- Seeding and mulching will immediately follow construction. Overseeding or reseeding will be performed as required until vegetation is established, including fertilizing when necessary.

- Temporary seeding will be provided in accordance with the CFC specifications. Areas that will not be disturbed will be seeded before construction is complete to reduce the area exposed to erosion.

- Silt will be removed from silt fences and straw bale barriers by the Contractor as needed and at the end of construction. The silt will be disposed of at the soil stockpile area.

- Remediation of problems identified during site inspection will be completed in a timely manner.

- Riprap lined drainage channels will be installed as shown on the CFC drawings to accommodate stormwater runoff.

- Temporary erosion and sediment control measures will be in place and functional before grading operations begin; maintained throughout the construction period; and repaired when damaged, destroyed, or when requested by the Construction Manager. Temporary measures may be removed at the beginning of the work day, but must be replaced at the end of the work day.

- Preconstruction vegetative ground cover will not be destroyed, removed or disturbed more than 20 calendar days prior to grading operations. Temporary soil stabilization materials will be applied within 7 days to all areas where grading has not been completed and has temporarily ceased and where grading activities are not anticipated to resume within 30 calendar days, unless approval is obtained from the Construction Manager.

- Excelsior matting will be used on all cut and fill slopes $4 \mathrm{H}: 1 \mathrm{~V}$ or steeper.

- Seed and mulch will be placed on all disturbed areas not covered by riprap, revetment mattress, or the relocated wetlands area within 10 days of completion of grading activities.

- Local, State, and Federal stormwater discharge quality regulations will be complied with. 
- Upper McCoy Branch floodplain will not be used as a transportation route for heavy equipment. Crossing of the Branch will be limited to one location, and erosion control measures will be utilized where the stream banks are disturbed. A pad of clean rock will be used at the crossing location. All temporary fill will be completely removed after construction is completed, and the ground contours will be returned to pre-construction conditions.

\subsection{INSPECTIONS AND ENVIRONMENTAL COMPLIANCE}

Weekly site inspections of the FCAP during construction activities will be made by the Construction Manager to confirm compliance with all environmental regulations and policies, including those set forth in this BMP Plan. A written record, including the date and findings of the inspection and notification of the appropriate parties, will be kept in the office of the Construction Manager.

Items to be inspected include, but are not limited to the following:

- conditions of erosion control

- condition of silt fences,

- drainageways,

- gully formation,

- excelsior matting,

- areas needing seeding or reseeding,

- verification that straw bales have been staked,

- riprap,

- condition of straw bales, and

- access roads;

- general housekeeping onsite;

- evidence of poor fueling practices;

- evidence of leaking tanks or equipment; and

- stream headwaters inspected for oil sheen, debris, siltation, or other disturbance.

Conditions noted in the inspection will be repaired immediately by the Contractor.

Periodic site inspections during the construction of the FCAP will be made by HSEA personnel to confirm compliance with all environmental regulations and policies, including those set forth in this BMP Plan. A written record, including the date and findings of the inspection and notification of the appropriate parties, will be kept in the HSEA office, in Building 9116.

Conditions noted during the construction phases that require corrective action will be reported to the Construction Manager for repair. 


\subsection{REFERENCES}

1. Y-12 Plant Best Management Practices (BMP) Plan. July 1992. Martin Marietta Energy Systems, Inc. Oak Ridge, Tennessee.

2. Environmental and Waste Management Policy. May 1985. ESH-14. Martin Marietta Energy Systems, Inc. Oak Ridge, Tennessee.

3. Spill Prevention, Control, and Countermeasures (SPCC) Plan for the Y-12 Plant. 1992. Y/SUB/92-21704/1. Revised Edition. Martin Marietta Energy Systems, Inc. Oak Ridge, Tennessee.

4. National Fire Protection Association. Standard System for the Identification of the Fire Hazards of Material. NFPA-704. Latest edition.

5. Virginia Erosion and Sediment Control Handbook. Third Edition, 1992. Virginia Department of Conservation and Recreation.

6. Tennessee Erosion and Sediment Control Handbook. July 1992. Tennessee Department of Environment and Conservation.

7. Guidance for Erosion and Sediment Control Measures Applicable to Construction Projects at the Y-12 Plant. May 1991. Y/SUB/91-57431C/1. Lockheed Martin Energy Systems, Inc. Oak Ridge, Tennessee. 


\section{APPENDIX A}

\section{LOCATION PLAN/SITE ACCESS PLAN}



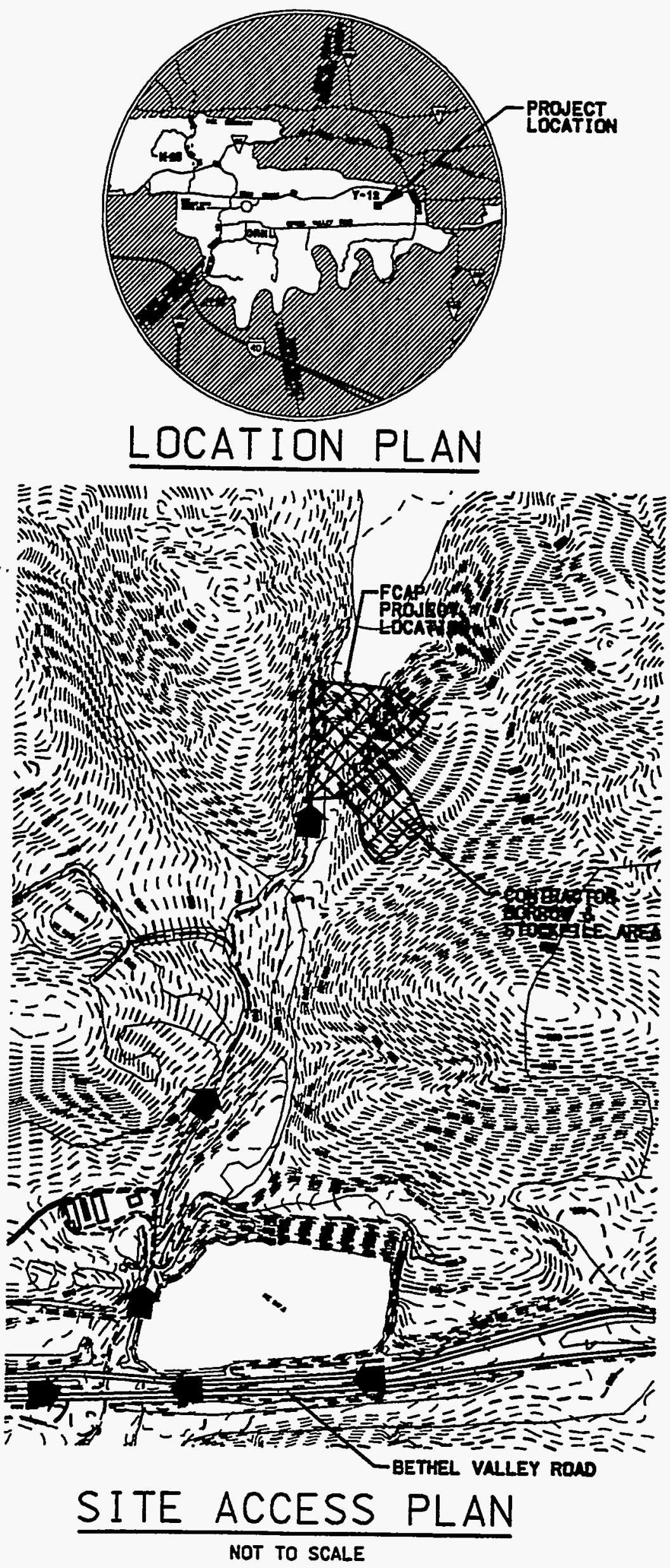
Y/ER-268

\section{DISTRIBUTION}

1. L. V. Asplund

2. E. T. Collins

3. J. A. Hodgins

4. L. D. Horton

5-6. A. K. Lee-DOE-OSTI

7-9. D. M. Matteo (3)

10. H. C. Newsome

11. P. L. Osborne

12-13. P. T. Owen (2)

14. G. M. Powers

15. J. H. Vanderlan

16. Central Research Library

17. ER Central Doc. Mgmt. Center-RC

18. B. Skokan U.S. Department of Energy, EM-423, Cloverleaf,19901 Germantown Road, Germantown, MD 20874

19. J. W. Wagoner II, Team Leader, Portsmouth/Paducah/Weldon Spring Team, Office of Environmental Restoration, U.S. Department of Energy, Cloverleaf Building, EM-424, 19901 Germantown Road, Germantown, MD 20874

20-21. R. C. Sleeman, Director, Environmental Restoration Division, DOE Oak Ridge Operations Office, P.O. Box 2001, Oak Ridge, TN 37831-8541 (2)

22. M. Reeves, DOE Oak Ridge Operations Office, P.O. Box 2001, Oak Ridge, TN 37831-8541

23. N. Kramer, MK-Ferguson of Oak Ridge Company, P.O. Box 2000, Oak Ridge, TN 37831

24. J. M. Stiner, MK-Ferguson of Oak Ridge Company, P.O. Box 2000, Oak Ridge, TN 37831

25. J. Townsend, MK-Ferguson of Oak Ridge Company, P.O. Box 2000, Oak Ridge, TN 37831

26. P. Dalfonso, Foster Wheeler Environmental Corp., 11 Union Valley Road, Oak Ridge, TN 37830 